\title{
The Significance And Utility of the Rules of Treaty Interpretation, as Encapsulated in the 1969 Vienna Convention on the Law of Treaties, for the Purpose of Ascertaining the Meaning of Treaty Provisions
}

\author{
Antlaşma Hükümlerinin Anlamını Tespit Etmek Amacıyla, 1969 Viyana Antlaşmalar \\ Hukuku Sözleşmesi'nde Özetlendiği Şekliyle, Antlaşma Yorumlama Kurallarının Önemi \\ ve Faydası
}

\section{Zora Kızılyürek* ${ }^{*}$}

\begin{abstract}
The interpretation of treaties is a complicated and problematic question at times. It is vital to interpret the law accurately in order to ascertain the correct meaning of treaty provisions and terms to provide a precise application. Consequently, rules of treaty interpretation play a significant role in purpose of finding distinct meaning of treaty provisions which is critical for both in the implementation stage and in mending any disputes afterwards. The aim of the treaty interpretation rules included in the 1969 Vienna Convention on the Law of Treaties (VCLT) is to bring precision and transparency to the agreements between member states. Therefore, in this paper the significance and the utility of the rules of treaty interpretation set in the 1969 Vienna Convention will be considered. This will be done by briefly considering the background of the convention. Then the rules of interpretation laid in article 31-33 such as ordinary meaning, context, purpose and object will be analysed. Additionally, the usefulness of these articles will be critically analysed with adequately supported legal opinions and a broad use of case law. This paper will claim that the rules of treaty interpretation of the VCLT is an extremely important tool in the interpretation of treaties.
\end{abstract}

Keywords

1969 Vienna Convention, Law of Treaties, Treaty interpretation, article 31, 32 and 33, interpretation rules

Öz

Antlaşmaların yorumlanması meselesi karmaşık ve sorunludur. Kesin bir uygulama sağlamak üzere antlaşma hükümlerinin ve şartlarının doğru anlamını tespit etmek için kanunu doğru yorumlamak çok önemlidir. Sonuç olarak, antlaşma yorumlama kuralları hem uygulama aşamasında hem de sonrasında herhangi bir anlaşmazlığın giderilmesinde kritik olan anlaşma hükümlerinin doğru anlamını bulma bakımından önemli bir rol oynamaktadır. VCLT'ye dahil edilen anlaşma yorumlama kurallarının amacı, üye devletler arasındaki anlaşmalara kesinlik ve şeffaflık getirmektir. Bu nedenle, bu makalede, 1969 Viyana Sözleşmesinde belirlenen antlaşma yorumlama kurallarının önemi ve faydası ele alınacaktır. Bu, Viyana antlaşmasının arka planı kısaca dikkate alarak yapılacaktır. Daha sonra olağan anlam, bağlam ve amaç gibi 31-33. maddelerde ortaya konan yorum kuralları incelenecektir. Ek olarak, bu maddelerin yararı, yeterince desteklenen hukuki görüşler ve geniş bir içtihat hukuku kullanımıyla eleştirel bir şekilde analiz edilecektir. Makale, VCLT'nin antlaşma yorumlama kurallarının antlaşmaların yorumlanmasında yararlı olduğunu savunacaktır.

\section{Anahtar Kelimeler}

1969 Viyana Sözleşmesi, Antlaşmalar Hukuku, Antlaşmanın yorumlanması, madde 31, 32 ve 33, yorumlama kuralları

\footnotetext{
* Corresponding Author: Zora Kızılyürek (LLM), University of Central Lancashire, Law School, Preston, UK. E-mail: zkizilyurek@uclan.ac.uk. ORCID: 0000-0002-5332-4805

To cite this article: Kizilyurek Z, "The Significance And Utility of the Rules of Treaty Interpretation, as Encapsulated in the 1969 Vienna Convention on the Law of Treaties, for the Purpose of Ascertaining the Meaning of Treaty Provisions", (2021) 70 Annales de la Faculté de Droit d'Istanbul 243. https://doi.org/10.26650/annales.2021.70.0008
} 


\section{The significance and utility of the rules of treaty interpretation, as encapsulated in the 1969 Vienna Convention on the Law of Treaties, for the purpose of ascertaining the meaning of treaty provisions}

\section{Introduction}

As Lord McNair quoted, "there is no part of the law of treaties which the text-writer approaches with more trepidation than the question of interpretation". ${ }^{1}$ Finding the meaning of a treaty provision is vital in understanding and applying the law. The Vienna Convention on the Law of Treaties is one of the core tools that states today are using to cooperate in international relations. ${ }^{2}$ This tool aims to bring precision and transparency to the agreements between member states. The rules on interpretation are found in article 31,32 and 33 of the Convention. ${ }^{3}$ The article 31 serves the purpose of providing the general rules of interpretation. The article 32 is the supplementary tool in the application of interpretation rules. The last one, article 33, regulates rules which apply to treaties which are written in two or more languages. ${ }^{4}$

\section{Brief background of the treaty}

The Vienna Convention on the Law of Treaties is an established scheme governing interrelationship of various rules of international law aiming to secure coherence and legal certainty. ${ }^{5}$ The convention only applies to treaties, which are written agreements, ruled by international law, ${ }^{67}$ and addresses questions such as application, withdrawal, validity, treaty formation, reservations and notably interpretation where the focus of this paper is. The significance of the rules of treaty interpretation derives from their very direct link to the enforcement of international law. ${ }^{8}$ Sovereign states are bound by the treaties they sign, and the interpretation rules have a utility to give effect to those treaties through interpreting them. ${ }^{9}$ Further, their significance is demonstrated in the fact that the VCLT grants a jurisdiction to the International Court of Justice to rule on cases where disputes arise due to the treaty interpretation rules. ${ }^{10}$ This treaty applies to international agreements between two or more states which are governed by international law, whether it is embodied in a single instrument or in two or more related instruments.

\footnotetext{
Plaintiff M70/2011/Plaintiff M106 of 2011 v Minister for Immigration and Citizenship

The Vienna Convention on the Law of Treaties

The Vienna Convention on the Law of Treaties article 31, 32 and 33

Ibid.

Philippe Sands, Treaty, Custom and the Cross-fertilization of International Law, 1 Yale Hum. Rts. \& Dev. L.J. (1998).

The Vienna Convention on the Law of Treaties article 2(1)(a)

Koowarta v Bjelke-Petersen (1982) 153 CLR 168

Cassese, Antonio, 2001. International Law, Oxford University Press, Oxford. P. 126

9 Sangroula, Yubaraj, International Treaties: Features and Importance from International Law Perspective (January 10, 2010). Available at SSRN: https://ssrn.com/abstract=2359978 or http://dx.doi.org/10.2139/ssrn.2359978

10 Bauer P, The Vienna Convention on the Law of Treaties, Encyclopaedia Britannica, (May 16, 2020), Available at $<$ https:// www.britannica.com/topic/Vienna-Convention-on-the-Law-of-Treaties>
} 


\section{Roles of article 31, 32 and 33 of the VCLT}

The rules of treaty interpretation are encapsulated in article 31-33 of the VCLT. ${ }^{11}$ As stated in the Guinea-Bissau v. Senegal, the correct methods on the interpretation of international customary law are codified under Article 31 and $32 .{ }^{12}$ If the wording of a treaty is clear, it is regulated under article 31 with general rules of interpretation .$^{13}$ If the wording is ambiguous, it is interpreted with supplementary provision of article 32 which includes a subjective element, a discretion of the interpreter. ${ }^{14}$ Article 33 on the other hand focuses on treaties authenticated in different languages. ${ }^{15}$

\section{IIII. Application of ordinary meaning under article 31}

Article 31 states that a treaty has to be interpreted in ordinary meaning of the terms, in good faith and within their context, purpose and object. ${ }^{1617}$ It further clarifies that where the wording of a treaty is clear there is an automatic application of article $31 .{ }^{18}$ The utility of this rule is to reflect parties' intention primarily through ascertaining the ordinary meaning of the treaty provisions. ${ }^{19}$ The 'ordinary meaning' is illustrated in the case of La Bretagne where a dispute arose relating to the ordinary meaning of the word 'fishing regulations'. Gardiner argues that ordinary meaning cannot be divorced from the context as they are immediately and intimately linked with the context. ${ }^{20}$ However, in this case the meaning has evolved since the time the agreement was concluded between parties thus leading to a dispute in ascertaining the meaning of the word. ${ }^{21}$ Thus as Linderfalk debated, interpretation rules may not always serve function as it lacks to specify whether the ordinary meaning of the word will be considered at the stage of concluding or interpreting the agreement. ${ }^{22}$ The words used in a treaty must reflect the intention of both parties and not what one negotiating party's intention alone.

11 The VCLT articles 31,32 and 33

12 Arbitral Award of 31 July 1989 (Guinea-Bissau v. Senegal) 14 February 1985 (1985) 77 ILR 636. (I.C.J. Reports 1991, pp. 69-70, para. 48). Available at $<$ https://jusmundi.com/en/document/decision/en-arbitral-award-of-31-july-1989-guineabissau-v-senegal-judgment-tuesday-12th-november-1991>

13 The VCLT article 31

14 Ibid

15 The VCLT article 33

16 Article 31(2) of the Vienna Convention on the Law of Treaties: context is restricted to preamble and annexes of the treaty

17 The Vienna Convention on the Law of Treaties article 31(1)

18 Merrills, J. (1971). Two Approaches to Treaty Interpretation. The Australian Yearbook of International Law Online. 4. 5582. 10.1163/26660229-004-01-900000005.

19 Namibia [1970] ICJ Rep 197116

20 Richard Gardiner. 'Treaty Interpretation'. Oxford: Oxford University Press, 2008. Pp. 165-176

21 'La Bretagne', Canada v France, Award, 17 July 1986 (1986) 82 ILR 591.

22 Ulf Linderfalk, Is Treaty Interpretation an Art or a Science? International Law and Rational Decision Making, European Journal of International Law, Volume 26, Issue 1, February 2015, Pages 169-189, https://doi.org/10.1093/ejil/chv008 


\section{V. 'Special' meaning under article 31}

Additionally, paragraph 4 states that ordinary meaning can be departed from and 'special' meaning can be given to words, if parties intended it. ${ }^{23}$ 'Special meaning includes a discretionary element when it comes to interpreting it. Brownlie stresses that this rule is too general and contradictory. ${ }^{24} \mathrm{He}$ emphasises that it leaves a high degree of freedom to the interpreters to establish intentions of the parties in giving a meaning to a word departed from its ordinary meaning. ${ }^{25}$ However, in ascertaining special meaning, interpreters shall take into account any treaties, instruments, subsequent practice, agreements, state of affairs and relevant rules. ${ }^{2627}$ This shows that the article is not narrowly drawn and there are various requirements to take into an account in interpreting. Consequently, as Orakhelashvili underlines, the interpreter has not got a freedom to interpret as spontaneously as s/he likes, and the rules of treaty interpretation are set. ${ }^{28}$ The aim of interpretation is to find the exact meaning of words parties has agreed when entering into an agreement which could be words which are not given ordinary meaning by the parties. ${ }^{29}$

\section{Interpretation within the context under article 31}

One of the other requirements of the article 31 is the context of a treaty while using the interpretation rules of the VCLT which is illustrated in the case of El Greco Ltd v Mediterranean Shipping Co. by Allsop J. He declared that if the piece of legislation giving effect to a treaty used the words from that particular treaty, then the legislation should be interpreted in the context of the words used in that treaty. ${ }^{30}$ As Brennan $C J$ added, 'the treaty interpretation is a holistic exercise' therefore, words should be interpreted within their context. ${ }^{31} \mathrm{~A}$ context would also include annexes or other agreements between parties. ${ }^{32}$ Art 31(3) states that 'There shall be taken into account, together with the context...(c) any relevant rules of international law applicable in the relations between the parties. ${ }^{33}$ Reading this provision in line with art 31(2), it shows that the treaty has to be interpreted in a broad perspective of international law and not in a narrow manner. In the case of Oil Platforms (Islamic Republic of Iran $v$ United

23 Ress, 'The Interpretation of the Charter', in B. Simma (ed.), The Charter of the United Nations: A Commentary, (1994) 25, at 30

24 I. Brownlie, Principles of Public International Law (6th edn, 2003), at 602.

25 Gabcikovo-Nagymaros [1977] ICJ Rep 7

26 Ibid. Art 31, para 3(b) applied in Y Le Bouthillier in Corten and Klein MN 43-44

27 ibid., Art. 31, para. 3(c)

28 Alexander Orakhelashvili. The Interpretation of Acts and Rules in Public International Law. Oxford: Oxford University Press, 2008.

29 Ibid.

30 El Greco (Australia) Pty Ltd v Mediterranean Shipping Co SA (2004) 140 FCR 296

31 Minister for Immigration \& Ethnic Affairs v Teoh (1997) 190 CLR 225, Brennan CJ agreeing with McHugh J

32 The Vienna Convention on the Law of Treaties article 31(2)

33 The Vienna Convention on the Law of Treaties article 31(3) 
States of America), the International Court of Justice found jurisdiction relating to a use of force on oil platforms, by applying a provision of another treaty between two states. ${ }^{34}$ The significance of the rules of treaty interpretation are the comprehensive interpretation approach and a very broad application it has.

\section{Object of the parties in ascertaining the meaning under article 31}

Considering the purpose requirement of article 31(1), a treaty should be interpreted in the light of its object and purpose. ${ }^{35}$ The utility of this rule is to give full effect to the treaty and find the purpose and objective of parties. ${ }^{36}$ As Waldock reasonably expressed, the impact of these treaty interpretation rules is that these requirements may create floodgates of vast interpretation. ${ }^{37}$ Van Damme however debates that these rules provide logic and order to a certain extent as the purpose and object of parties play a crucial role in ascertaining a meaning of a treaty. These requirements can be seen as a burden on the interpreter as well as an empowerment. ${ }^{38}$ This is a great example which shows the significance of the rules of treaty interpretation of the VCLT as the role of an interpreter's understanding can be critical in application of these rules. Nevertheless, there are certain decisions such as Jones $v$ Saudi Arabia where the House of Lords interpreted the Torture Convention in a narrow manner, showing that purpose and object requirement do not necessarily open flood gates. ${ }^{39}$

\section{Article 32 and its supplementary application}

Examining the next important article, article 32 deals with the use of supplementary means of treaty interpretation in relation to article $31 .^{40}$ It is used if the wording is ambiguous, hence why it includes wider discretion of the interpreter and a broader subjective element compared to article $31 .{ }^{41}$ As decided in the Qatar $v$ Bahrain case, the fundamental concern of this provision is the materials and information which can be used for interpretation such as preparatory work or the occurrences of its conclusion. ${ }^{42}$ The preparation stage or other circumstances which led to the conclusion of treaties can play a critical role in interpreting intentions of the parties. ${ }^{43}$

34 Oil Platforms (Islamic Republic of Iran v United States of America) [2003] ICJ 4 at [41]-[45]

35 Cf. Lauterpacht, 'Restrictive Interpretation and the Principle of Effectiveness in the Interpretation of Treaties', 26 BYBIL (1949) 284

36 The Island of Palmas Case (Scott, Hague Court Reports 2d 83 (1932)

37 Third Report of the Special Rapporteur, Sir Humphrey Waldock (Sixteenth Session of the ILC (1964)), Doc. A/CN.4/167 and Add.1-3, ILC Yb. 1964, II, 5, at 60-61

38 Isabelle Van Damme. Treaty Interpretation by the WTO Appellate Body. Oxford: Oxford University Press, 2009.

39 Jones v. Ministry of Interior of the Kingdom of Saudi Arabia. Case No. [2006] UKHL 26.

40 Dörr, Oliver \& Schmalenbach, Kirsten. (2012). ‘Article 32. Supplementary means of interpretation'. 10.1007/978-3-64219291-3 35 .

41 Ibid.

42 Maritime Delimitation and Territorial Questions between Qatar and Bahrain (Qatar v. Bahrain) 1994/2

43 Navigational and Related Rights [2009] ICJ Rep 213 
Therefore, this rule of treaty interpretation is significant as it provides flexibility in ascertaining the meaning of treaty provisions. On the other hand, as Gardiner highlights, this rule does not produce a formula to create an irrebuttable interpretation or provide a scientifically proven result. ${ }^{44}$ This is due to the complexity such wide discretion may create which would amount certain disputes to be left unresolved due to the lack of objectivity.

\section{VIIII. General application vs. supplementary application}

In analysis of the utility of these two rules, Linderfalk states that their usefulness is impeded by the confusion they generate through creating a wide range of opinions in regard to their normative content. ${ }^{45}$ Rosenne further stresses that these rules are too general, subsidiary and not structured in a hierarchical way. ${ }^{46}$ Arguing a contrary view, the rules are specified in their functionality and there is a clear general versus supplementary application. For example, article 31 starts as 'the treaty shall be interpreted' which shows a mandatory use of language. On the other hand, article 32 states 'may be had to supplementary means' which is not compulsory and only supplementary therefore the interpreter has a choice to use it. ${ }^{47}$ The significance of these rules are the useful direction they give in determining how to interpret a treaty and a clear set of roles each rule has. The convention overall is based on a textual approach and not on an interpretation approach. Hence why article 31 primarily sets general rules of application whereas article 32 has a supplementary role. The supplementary nature of this article derives from the need to ensure that predatory work is not used as an alternative, distinct from general rules of article 31 but rather a supporting tool. ${ }^{48}$

\section{$X$. Article 33 and its role in interpreting treaties written in more than one language}

The final treaty interpretation rule to consider is article 33 which regulates the interpretation of treaties in two or more languages. Fernandez explains that language is an element of sovereignty that a state can express itself through. ${ }^{49}$ Therefore, disagreements on interpretations can occur in texts of the treaty with different languages. ${ }^{50}$ The utility of article 33 is to resolve these disputes. The implication

44 Richard Gardiner. ‘Treaty Interpretation’. Oxford: Oxford University Press, 2008. Pp. 165-176

45 Linderfalk U, 'Is the Hierarchical Structure of Articles 31 and 32 of the Vienna Convention Real or Not? Interpreting the Rules of Interpretation (2007) 54 Netherlands international law review 133

46 S Rosenne, Developments in the Law of Treaties (1945-1986) (CUP, Cambridge 1989) 182-83.

47 R Gardiner, Treaty Interpretation (OUP, Oxford 2008) 120.

48 Y Le Bouthillier in Corten/Klein Art 32 MN 32-38. The traditional doctrinal controversy on the use of preparatory work (1971) 11 IJIL 39, 3957.

49 Carlos Fernández de Casadevante Romani. Sovereignty and Interpretation of Inter- national Norms. Berlin: Springer, 2007

50 Ibid. 
of this rules is considering the object and purpose of the treaty to ascertain which text reconciles the most. ${ }^{51}$ In the case of Habsburg-Lorraine House $v$ The Polish State Treasury, the court ascertained the meaning of the treaty by comparing different texts. $^{52}$

\section{Importance of treaty interpretation rules}

The importance of the rules of treaty interpretation is, it is widely used in international courts. Fitzmaurice views treaty interpretation rules captured in the VCLT as being multifaceted. ${ }^{53}$ The rules contain wide-ranging interpretative principles, correspondingly give broad powers of interpretation to international courts and tribunals. ${ }^{54}$ Different courts use interpretation rules differently. ${ }^{55}$ For example, the ICJ and WTO's Appellate Body treat these rules as general or customary international law. ${ }^{56}$ On the contrary, the European Court of Human Rights and CJEU rely on dynamic interpretation distinguishing it from the convention's textual approach. ${ }^{57}$ For example in the case of Soering $v$ the United Kingdom concerning the abolishment of death penalty, the ECtHR ruled that 'the convention is a living instrument which must be interpreted in a manner consistent with today's understanding of justice standards'. ${ }^{58}$ Whereas the Chicken Cuts case where the WTO's Appellate Body used the textual approach to settle the dispute.$^{59}$ Hence this shows the significance and utility of these rules as they can be broadly applied in different international courts, in a multi-dimensional level to respond to diverse needs of treaty interpretation. ${ }^{60}$

\section{Conclusion}

In conclusion, as Kolb said, international law is law in action which develops constantly. ${ }^{61}$ The VCLT plays a significant role in balancing the need to provide legal certainty to law and a need for flexibility in interpreting treaties which can be incomplete and lacking precision. The rules of treaty interpretation in the VCLT provides a certain set of standards such as interpreting words in their ordinary

51 VCLT Article $33(4)$

52 Annual Digest of International Law Cases, 1929-1930, case No. 235.

53 Gerald Fitzmaurice, Vae Victis or Woe to the Negotiator? Your Treaty or Our Interpretation of It, 65 AJIL 358, 370 (1971)

54 Richard Gardiner. ‘Treaty Interpretation'. Oxford: Oxford University Press, 2008. Pp. 165-176

55 Richard Gardiner. 'Treaty Interpretation'. Oxford: Oxford University Press, 2008. Pp. 165-176

56 Fitzmaurice reviews Treaty Interpretation by Richard Gardiner and On the Interpretation of Treaties: The Modern International Law as Expressed in the 1969 Vienna Convention on the Law of Treaties by Ulf Linderfalk.

57 The Court of Justice of the European Union, Koen Lenaerts, 'Interpretation and the Court of Justice: A Basis for Comparative Reflection' (2007) 41(4) The International Lawyer at 1011-32.

58 Soering v United Kingdom 161 Eur. Ct. H.R. (ser. A) (1989)

59 WTO Appellate Body EC - Customs Classification of Frozen Boneless Chicken Cuts WT/DS269/AB/R (2005), paras 282-309.

60 Malgosia Fitzmaurice, Dynamic Interpretation of Treaties, Part I, 2008 HAGUE Y.B. INT'L L. 101.

61 Robert Kolb. Interpretation and creation of international law. Outline of a Modern Legal Hermeneutics for Public International Law. Brussels: Bruylant, 2006. Pp. 959 
meaning as well as flexible rules such as supplementary rules to interpret words broadly. There is a good balance in this two-stage process considering the textual approach the VCLT has. The main focus is the ordinary meaning of words, yet there is a flexibility. In applying article 31(4) or article 32, interpreters may have too much discretion to ascertain meaning of the treaties. This could lead to uncertainty and complexity due to the subjective element of interpretation. As discussed above some scholars may doubt the extent of utility these rules have as sometimes giving ordinary meaning to words may also lead to confusion. However, in general these rules play a significant role to bring precision to the meaning of treaties thus strengthening international cooperation. Their utility is further illustrated in the fact that they can be enforced broadly both in respect of different executive agencies and the level of freedom there is in the interpretation methods.

\footnotetext{
Peer-review: Externally peer-reviewed.

Conflict of Interest: The author has no conflict of interest to declare.

Grant Support: The author declared that this study has received no financial support.

Hakem Değerlendirmesi: Dış bağımsız.

Çıkar Çatışması: Yazar çıkar çatışması bildirmemiştir.

Finansal Destek: Yazar bu çalışma için finansal destek almadığını beyan etmiştir.
}

\section{Bibliography}

\section{International Law}

The Vienna Convention on the Law of Treaties (VCLT) (1969) 1155 UNTS 331; 8 ILM 679; [1974] ATS 2

\section{Cases}

Annual Digest of International Law Cases, 1929-1930, case No. 235.

Arbitral Award of 31 July 1989 (Guinea-Bissau v. Senegal) ICJ (International Court of Justice)

El Greco (Australia) Pty Ltd v Mediterranean Shipping Co SA (2004) 140 FCR 296

Gabcikovo-Nagymaros [1977] ICJ Rep 7

Jones v. Ministry of Interior of the Kingdom of Saudi Arabia. Case No. [2006] UKHL 26.

Kasikili/Sedudu Island (Botswana/Namibia), Judgment, 13 December 1999, ICJ Reports (1999) 1045.

Koowarta v Bjelke-Petersen (1982) 153 CLR 168

Maritime Delimitation and Territorial Questions between Qatar and Bahrain (Qatar v. Bahrain) $1994 / 2$

Minister for Immigration \& Ethnic Affairs v Teoh (1995) 183 CLR 273

Namibia [1970] ICJ Rep 197116

Navigational and Related Rights [2009] ICJ Rep 213

Oil Platforms (Islamic Republic of Iran v United States of America) [2003] ICJ 4 at [41]-[45] 
Plaintiff M70/2011/Plaintiff M106 of 2011 v Minister for Immigration and Citizenship

Soering v United Kingdom 161 Eur. Ct. H.R. (ser. A) (1989)

The Island of Palmas Case (Scott, Hague Court Reports 2d 83 (1932)

WTO Appellate Body EC - Customs Classification of Frozen Boneless Chicken Cuts WT/DS269/ $\mathrm{AB} / \mathrm{R}(2005)$

\section{Books}

Orakhelashvili A, The Interpretation of Acts and Rules in Public International Law (Oxford University Press, 2008).

De Casadevante Romani, C.F. Sovereignty and Interpretation of Inter- national Norms.

(Springer, 2007).

I. Brownlie, Principles of Public International Law (6th edn, 2003), at 602.

Van Damme, I. Treaty Interpretation by the WTO Appellate Body. (Oxford University Press, 2009).

Lenaerts K, Interpretation and the Court of Justice: A Basis for Comparative Reflection (The International Lawyer, 2007)

Lo, C., Treaty Interpretation Under the Vienna Convention On The Law Of Treaties A New Round Of Codification. (Springer Nature, 2017)

R. Jennings, 'General Course on Principles of International Law' (1967)

Kolb, R. Interpretation and creation of international law. Outline of a Modern Legal Hermeneutics for Public International Law. (Bruylant, 2006).

Linderfalk, U. On the Interpretation of Treaties. The Modern International Law as Expressed in the 1969 Vienna Convention on the Law of Treaties. (Springer, 2007).

\section{Articles}

Dörr, Oliver \& Schmalenbach, Kirsten. (2012). ‘Article 32. Supplementary means of interpretation'. 10.1007/978-3-642-19291-3_35.

Gerald Fitzmaurice, Vae Victis or Woe to the Negotiator? Your Treaty or Our Interpretation of It, 65 AJIL 358, 370 (1971)

Merrills, J. (1971). Two Approaches to Treaty Interpretation. The Australian Yearbook of International Law Online. 4. 55-82. 10.1163/26660229-004-01-900000005.

Zemanek, K., 2021. Vienna Convention on The Law of Treaties. [online] United Nations Audiovisual Library of International Law, p.2. Available at: https://legal.un.org/avl/pdf/ha/vclt/vclt-e.pdf

\section{Journals}

Bauer P, 'The Vienna Convention on the Law of Treaties, Encyclopaedia Britannica', (May 16, 2020), Available at <https://www.britannica.com/topic/Vienna-Convention-on-the-Law-ofTreaties $>$ accessed at 15 th December 2020 .

Linderfalk U, 'Is the Hierarchical Structure of Articles 31 and 32 of the Vienna Convention Real or Not?' Interpreting the Rules of Interpretation (2007) 54 Netherlands international law review 133

Mbengue M M, 'Rules of Interpretation (Article 32 of the Vienna Convention on the Law of Treaties)' Law Journal, Volume 31, Issue 2, Spring 2016, Pages 388412 
Sands P, 'Treaty, Custom and the Cross-fertilization of International Law', 1 Yale Hum. Rts. \& Dev. L.J. (1998).

Sangroula, Yubaraj, 'International Treaties: Features and Importance from International Law Perspective' (January 10, 2010).

Pauwelyn, Joost and Elsig, Manfred, 'The Politics of Treaty Interpretation: Variations and Explanations Across International Tribunals' (October 3, 2011).

Y Le Bouthillier in Corten/Klein 'The traditional doctrinal controversy on the use of preparatory work' (1971) 11 IJIL 39, 3957.

\section{Reports}

Third Report of the Special Rapporteur, Sir Humphrey Waldock (Sixteenth Session of the ILC (1964)), Doc. A/CN.4/167 and Add.1-3, ILC Yb. 1964, II, 5, at 60-61

Fitzmaurice reviews Treaty Interpretation by Richard Gardiner and On the Interpretation of Treaties: The Modern International Law as Expressed in the 1969 Vienna Convention on the Law of Treaties by Ulf Linderfalk. 